\title{
ENTRE CINEMA E ANTROPOLOGIA: PARENTESCO E ANIMISMO EM "MIDSOMMAR", DE ARI ASTER
}

\author{
Rafael Siqueira Machado ${ }^{1}$ \\ Adrielle Luchi Coutinho Bove ${ }^{2}$
}

\begin{abstract}
Resumo
O presente artigo se objetiva em aproximar certas reflexões antropológicas do filme "Midsommar" (2019) de Ari Aster na forma de uma afinidade eletiva, para citar o termo weberiano. A defesa feita aqui é a possibilidade de tratar "Midsommar" como um material capaz de incitar e retomar diversas problematizações antropológicas acerca do parentesco e animismo na forma de um filme. Reconhece-se aqui que tal proximidade é virtual e constituída a partir da presente reflexão ao tratar o filme como material etnográfico passível de análise, ainda que a referência à antropologia se dê em alguns momentos por intermédio de dois personagens identificados como antropólogos. Ao apresentar a reflexão sobre o parentesco, as questões aqui tangenciadas remetem-se aos temas do parentesco americano, construção e comparação das noções de incesto e a ideia de mutualidade do ser como elemento central no filme. Já sobre o animismo, este é apresentado tanto como elemento intrinsecamente ligado à questão do parentesco e como um posicionamento ético com implicações comportamentais fundadas em princípios e noções com implicações ontológicas.
\end{abstract}

Palavras-Chave: Midsommar. Parentesco. Animismo. Cinema. Antropologia.

Between Cinema and Anthropology: kinship and animism in "Midsommar", by Ari Aster

\begin{abstract}
This article aims to bring together certain anthropological reflections from the film "Midsommar" (2019) by Ari Aster in the form of an elective affinity, to quote or a Weberian term. The defense made here is the possibility of treating "Midsommar" as a material capable of inciting and recovering various anthropological problems related to kinship and animism in the form of a film. See here that such proximity is virtual and starts from this reflection to treat films as ethnographic material that can be analyzed, even with reference to anthropology, if you have a few moments through two characters shown as anthropologists. When presenting a reflection on the subject, as the questions presented here refer to themes related to the American, the construction and comparison of notions of incest and the idea of mutuality of being as a central element in the film. As for animism, it is presented both as an element intrinsically linked to the issue of the relative and as an ethical position with behavioral implications based on principles and notions with ontological implications.
\end{abstract}

Keywords: Midsommar. Kinship. Animism. Movie theater. Anthropology.

\footnotetext{
1 Rafael Siqueira Machado: graduado em Ciências Humanas pela UFJF (2013); graduado em Ciências Sociais pela UFJF (2016), mestre em Ciências Sociais pela UFJF (2018), doutorando em Ciências Sociais pela UFJF. E-mail: faelborgir@hotmail.com.

2 Adrielle Luchi Coutinho Bove: graduada em Ciências Humanas pela UFJF (2013); graduada em Ciências Sociais pela UFJF (2016), mestra em Ciências Sociais pela UFJF (2017), doutoranda em Ciências Sociais pela UFJF. E-mail: adrielleluchi@gmail.com.
} 


\section{Introdução}

Cinema e antropologia possuem diversas aproximações potenciais, seja na forma de filmes etnográficos, documentários ou mesmo grandes produções que apresentam potencial analítico e/ou pedagógico para a antropologia, seja de forma mais direta ou nos entremeios de sua narrativa. E de certa maneira, este é o caso de "Midsommar", filme produzido e dirigido pelo estadunidense Ari Aster em 2019. Apresentando uma narrativa que parte de uma tragédia pessoal da personagem Dani (Florence Pugh) em que esta perde seus pais e irmã, fazendo com que seu momento de luto gere o impulso necessário para que Christian (Jack Reynor), seu namorado, a convide para uma viagem em grupo ao vilarejo de Hårga $a^{3}$, na região de Hälsingland - Suécia, lugar em que Christian e seu amigo Josh (William Jackson Harper), pretendem realizar uma pesquisa antropológica sobre rituais pagãos de solstícios, com ênfase no ritual de Midsommar, um ritual que ocorre a cada noventa anos com duração de nove dias, sendo um evento absolutamente central na comunidade, o que gera o interesse de pesquisa dos dois antropólogos. Tal viagem é realizada também por outro amigo do grupo, Mark (Will Pouter), que a faz apenas por curiosidade, não por interesse acadêmico. Segundo o filme, a viagem ao local apenas é possível por outro amigo, Pelle (Vilhelm Blomgren), ter nascido e crescido na comunidade, tendo posteriormente se mudado para os EUA e conhecido os outros personagens, que sugere o local e ritual como possível tema de pesquisa à Josh e Christian. Em Hårga, os personagens defrontamse com uma série de rituais e costumes variados, incluindo rituais de sacrifício humano, uso de entorpecentes e etc, implicando em uma série de questões que podem ser dialogadas por um viés antropológico, sendo algumas destas aqui mobilizadas. Ao longo filme, tais eventos tanto causam desconforto nos visitantes como suas próprias condutas em relação aos sacrifícios, entorpecentes e etc, são métricas balizadoras para que os habitantes do vilarejo os tomem como possíveis sacrifícios também ao longo da estadia na vila, elemento este que conduz a narrativa do longa.

De certa maneira, o objetivo do presente trabalho é tomar a comunidade fictícia de Hårga como base de análise etnográfica, como se fosse real, para que seja possível refletir sobre alguns dos

\footnotetext{
${ }^{3}$ Comunidade rural fictícia localizada no interior da Suécia. Se caracteriza pelo afastamento de qualquer centro urbano, em meio à natureza. Algumas dezenas de pessoas moram no local e, ao invés de casas individuais, as pessoas moram em grandes casas e dividem o espaço interno. Como fica claro no filme, os habitantes compartilham de uma orientação "religiosa" voltada ao paganismo nórdico.
}

CSOnline - Revista Eletrônica de Ciências Sociais, Juiz de Fora, n. 32 (2020). 
temas abordados no longa. Dentre as dificuldades de tal intento, talvez a mais grave seja a limitação de análise possível de um material (fictício) circunscrito na extensão do filme, que é de 2 horas e 50 minutos $^{4}$. A intenção é aproximar as reflexões antropológicas ao conteúdo em si do longa e incitar a possibilidade de pensar um filme pelo viés da antropologia, tomando seu conteúdo como um tipo de material etnográfico. A partir disso, diversas construções opõem uma vivência existencial ocidental comum aos personagens do filme (visitantes) e os habitantes de Hårga, produzindo elementos no filme que fundamentam as reflexões aqui presentes.

Vale notar que este artigo não é a primeira tentativa de analisar cientificamente "Midsommar", cabendo à Tsugami $(2019)^{5}$ o trabalho de explorar na forma de uma resenha as referências históricas e arqueológicas presentes no filme, no que diz respeito aos rituais, costumes e símbolos dos povos nórdicos do período précristão. Tendo em vista sua ênfase em tais temáticas, o presente trabalho busca pensar o filme sob outra égide, tratando o filme como um tipo de etnografia capaz de fornecer material para reflexões antropológicas direcionadas a duas temáticas contextualmente imbricadas: o parentesco e o animismo. Tais temáticas são aqui analisadas face ao próprio longa, isto é, este recorte se dá pela defesa aqui feita de que os dois temas (parentesco e animismo) são elementos centrais da vida em Hårga. Desta maneira, as análises aqui realizadas são feitas através de cortes discricionários, falas recortadas e contextualizadas que são tratadas como eventos com potencial etnográfico para a análise, tendo sua ênfase recaída em fenômenos relevantes à vida em Hårga. Tais cenas e falas recortadas possuem mais ou menos relevância para a compreensão narrativa do filme, ainda que não seja nosso objetivo trabalhar com a narrativa, em si, do filme.

\section{Parentesco como base fundante de Hårga}

O parentesco é um campo de estudo antropológico absolutamente caro à tal ciência, permeando análises desde as primeiras contribuições do evolucionista Lewis Morgan, passando por Malinowski, Radcliffe-Brown, Lévi-Strauss, Schneider, Strathern e outros. A partir desta relevância, a presente proposta da sessão é

\footnotetext{
"A versão aqui analisada é a chamada "director's cut" ou "versão do diretor", caracterizada por incluir cenas deletadas em comparação à versão levada ao cinema. A diferença de tempo é estimada em 30 minutos.

${ }^{5}$ Agradecemos à autora por ceder a resenha completa.
}

CSOnline - Revista Eletrônica de Ciências Sociais, Juiz de Fora, n. 32 (2020). 
exercitar algumas destas reflexões para pensar o filme "Midsommar" e como a linguagem do parentesco atravessa a obra como um todo. Assim, esta sessão irá elaborar, em três perspectivas analíticas, possíveis aproximações entre o dito filme e reflexões sobre o parentesco. Estas três perspectivas serão, a saber: a construção das concepções de parentesco entre os americanos que se refletem em "Midsommar", a questão do incesto e a comparação entre americanos e habitantes de Hårga e, por fim, a problemática da mutualidade do ser em Sahlins e a constituição desta perspectiva como elemento fundante do parentesco em Hårga.

\section{1) O Parentesco Americano}

Destarte, podemos iniciar as reflexões a partir das primeiras cenas do filme, em que a personagem Dani surge em tormento por conta de tragédias familiares. $\bigcirc$ tom escuro, noturno ${ }^{6}$, presente nestas primeiras cenas antecipa o drama pessoal da personagem como um prenúncio de mortes vindouras. Sua irmã, apresentada como alguém com problemas psicoemocionais é a responsável por assassinar o pai e a mãe de Dani, morrendo também no processo de intoxicação por gás, propositalmente espalhado. Nesta primeira parte, Dani se coloca como uma personagem claramente deslocada após o ocorrido, buscando no fugaz namorado Christian - um sujeito propositalmente apresentado como egoísta pouco preocupado com o sofrimento da namorada - um pouco de apoio. Sem os pais e a irmã biológica, Dani é introduzida como uma órfã sem bases sólidas de apoio, solitária. Neste sentido, a ideia de família consanguínea funciona como forte marcador que se opõe à solidão. Reforça-se a importância dessa família como padrão relacional pela via inversa: a falta dela implica, consequentemente, na solidão. Justamente nas cenas em que Dani chora, aparece sozinha e vivencia o luto da perda familiar, que esta ênfase na família dada por relações consanguíneas é mais central.

Tal modelo familiar genericamente definido como ocidental, expresso em "Midsommar" através da família de Dani, fundado em relações consanguíneas entre sujeitos que compartilham o mesmo material biogenético, definindo as aproximações relacionais a partir deste grau de compartilhamento, é apresentado em termos antropológicos a partir das contribuições de David Schneider (2016).

\footnotetext{
${ }^{6}$ Que se opõe a onipresença da luz do dia na comunidade sueca em que os personagens se dirigem posteriormente. Em Hårga, a luz do dia dura quase 24 horas, por conta do verão nesta região sueca.
}

CSOnline - Revista Eletrônica de Ciências Sociais, Juiz de Fora, n. 32 (2020). 
Este autor funda sua base analítica a partir da construção dicotômica entre natureza e cultura como fruto do pensamento ocidental, que também ocupa importante lugar como condição ontológica sine qua non nos trabalhos antropológicos predecessores. Tratando o mencionado parentesco como de tipo "americano", que remete a uma série de construções simbólicas fundadas em um sistema cultural bem definido, o parentesco americano não é tratado por Schneider (2016) como uma expressão da realidade, mas algo "que representa alguma coisa, ou algumas outras coisas, onde não há nenhuma relação necessária ou intrínseca entre símbolo e aquilo que ele simboliza" (SCHNEIDER, 2016, p.13). Isto é, os termos de parentesco e as relações designadas simbolizam parte de um conjunto cultural específico, não uma realidade externa7. Este primeiro ponto é central tanto para a compreensão do pano de fundo que envolve as análises de Schneider (2016) quanto um mote para pensar as relações de parentesco aqui definidas como de tipo ocidental ${ }^{8}$, que definem este primeiro momento do filme.

Para os americanos, segundo Schneider (2016), a ideia de parente se dá por uma dupla via de potencialidades: o sangue e/ou o casamento. Os parentes de sangue são aqueles que, se apropriando do campo científico da biogenética - definida como a área de conhecimento que fornece as verdades sobre o parentesco - compartilham material genético (pai, mãe, tios, primos, avós). Já os parentes por casamento (ou afinidade) são aqueles decorrentes de uma união por casamento, mas que não compartilham material genético (sogro, sogra, cunhado, genro, nora). Nesta dicotomia, a operação natureza e cultura opera explicitamente, tratando os parentes por afinidade como resultado do artifício cultural, da relação construída; ao passo que o parentesco consanguíneo é do reino do dado, não do escolhido, variando apenas os graus de distanciamento definidos pelo compartilhamento substancial, a partir de conhecimentos científicos.

\footnotetext{
${ }^{7}$ Este é um ponto importante no autor, pois, por exemplo, a palavra "tio" reflete um campo relacional que envolve sobrinhos, irmãos e etc, ainda que a ideia de "tio" se dê enquanto símbolo, uma abstração representativa sem ligação com o mundo externo, mas inerentemente ligado a uma unidade cultural. "[...] a questão não é qual coisa elas representam no mundo real, objetivo, de fora, ainda que com a palavra 'cachorro', nós possamos pegar esse animal concreto [...]. A questão é quais coisas diferentes essa palavra representa". (SCHNEIDER, 2016, p.15).

${ }^{8}$ Ainda que Schneider (2016) aponte a palavra "americano" para designar limites geográficos e culturais de alcance de seu modelo, propõe-se aqui inferir este modelo para outros contextos, por isso o uso da palavra "ocidental". Tem-se em vista também que este modelo cabe talvez ser pensado como quase um tipo ideal weberiano, mais fluido e múltiplo na prática, mas que possui um modelo geral relativamente presente, tal como a ser apresentado em seguida.
}

CSOnline - Revista Eletrônica de Ciências Sociais, Juiz de Fora, n. 32 (2020). 
Em termos teóricos, o salto do pensamento de Schneider (2016) reside em sua ênfase no simbolismo. A realidade das coisas reside em suas existências enquanto constructos culturais ${ }^{9}$ particulares, não em supostas equivalências externas. A ciência seria uma unidade cultural que relaciona símbolos na constituição de seus saberes. O parentesco americano, ao se apropriar dos símbolos científicos, em especial o "sangue", trata tais relações derivadas como elementos naturais e universais. Porém, para o autor, a ideia de natureza se dá como um constructo cultural formada por símbolos variados que, por sua vez, correlacionam elementos de forma específica e ontologicamente não-obrigatória. A existência de um mundo externo não é tema tratado por Schneider (2016), mas sim que as ideias que temos sobre ele que são símbolos, formulações culturais específicas, não reflexos em si do mundo. Portanto, a ciência, nos termos de Schneider (2016), não expressa o mundo real em si, mas sim abstrações simbólicas (sangue, DNA, etc) que relacionam coisas e constroem nossas concepções culturais sobre parentesco.

A partir de Schneider (2016), duas inferências podem ser aqui postuladas em relação ao filme: 1) O modelo americano, ao se colocar como símbolo orientador das relações de parentesco, opõe natureza e cultura. Ao relacionar tais questões ao caso de Dani, podemos destacar que sua solidão deriva diretamente da morte dos pais e irmã, os símbolos centrais do parentesco consanguíneo, aquele definido pela biologia, insubstituível e inquebrável. Por sua vez, as cenas posteriores à morte da família mostram a titubeante base de apoio de Christian - um namorado distante, que enfatiza em uma conversa com amigos a intenção precipitar o fim do namoro (podendo se definir como uma relação mais fluida, sem o forte comprometimento legal que o casamento implica). A fluidez da relação (um namoro, não casamento), acrescida da intenção de término por parte de Christian reforça que a outra base de sustentação do parentesco (por afinidade), encontra-se radicalmente abalada, acrescendo a solidão de Dani, ao invés de apaziguá-la. A solidão de Dani, pensada a partir da linguagem do parentesco e, especificadamente, o modelo americano, então se explica pela quebra das relações consanguíneas e a fragilidade das relações prévias ao parentesco por afinidade. 2) Ao deslocar o modelo americano fundado na dicotomia natureza (relações consanguíneas) e cultura (relações de

\footnotetext{
9 Daí vem sua reflexão (p.14) sobre a existência de fantasmas ser equivalente a de corpos mortos, pois ainda que a empiria descarte a existência de fantasmas, sua realidade em termos simbólicos como constructo cultural importante em diversos contextos não se anula.
}

CSOnline - Revista Eletrônica de Ciências Sociais, Juiz de Fora, n. 32 (2020). 
afinidade) para o âmbito simbólico, a pressuposição desta forma de parentesco como expressão objetiva de aspectos naturais é desconstruída por Schneider (2016), permitindo novas relações analíticas na comparação com outros modelos. Ao menos desde Lewis Morgan (1871) no campo da antropologia e sua dicotomização produzida entre parentesco descritivo (ocidental, que descreve relações reais, presentes na natureza) e classificatório (todos aqueles que classificam sob o mesmo termo relações ocidentalmente tratadas como distintas), o parentesco de modelo ocidental é tratado como lugar privilegiado de expressões naturais. Em relação ao filme, estas são as bases de apoio de Dani: a família consanguínea - morta no início do filme - e Christian, um namorado em vias de término, projetado como único possível suporte de apoio que poderia ser caracterizado como parte de uma relação de parentesco por afinidade, mas que pela sua frieza em relação à Dani, não permite a constituição dessa relação, ocasionando a solidão da personagem. Se, partir de Schneider (2016), podemos tanto destacar a constituição característica deste modelo de parentesco "americano" que nos permite guiar as relações de Dani constituídas e destruídas, o autor também permite destacar a relativização deste modelo americano ${ }^{10} \mathrm{em}$ relação a outros possíveis, pois destaca que este modelo não é reflexo de uma natureza universal, o que nos dá suporte para pensar em termos de planicidade comparativa, principalmente ao expressar os confrontos e comparações do parentesco americano ao modelo de Hårga (comunidade sueca em que se passa o filme).

\section{2) O incesto em duas perspectivas}

Seguindo adiante e tomando a proposição do parentesco americano schneideriano como pano de fundo existencial que orienta o pensamento dos personagens do filme externos à Hårga, cabe destacar outro ponto essencial ao filme que se liga à questão do parentesco de forma essencial, a saber, o incesto. Duas cenas são aqui destacadas por abordarem a questão do incesto, hora conformando uma visão ocidental supostamente compartilhada, hora destoando da mesma e revelando novas perspectivas sobre a prática. Ambas cenas possuem ampla relevância para 0 argumento aqui abordado, ainda que para a narrativa do longa, tenham menor expressão.

\footnotetext{
${ }_{10}$ Que não mais se dá como expressão de uma natureza externa, compartilhada universalmente por todos os contextos humanos possíveis.
}

CSOnline - Revista Eletrônica de Ciências Sociais, Juiz de Fora, n. 32 (2020). 
Na primeira cena, momento em que os personagens já se encontram há alguns dias em Hårga e Christian - um dos antropólogos interessados em estudar os "ritos" de Hårga - inicia o desenvolvimento da pesquisa, desenvolve uma conversa com um dos habitantes locais, Valentin - que apenas participa do filme neste momento - sobre os casamentos e os "riscos" do incesto, haja vista o tamanho reduzido da comunidade. A preocupação de Christian se dá a partir da percepção do isolamento em que a comunidade se encontra referente à outros vilarejos e sua condição aparentemente fechada, que dificulta a entrada de novos moradores. Portanto, o antropólogo chama a atenção para a questão do incesto enquanto um "risco", refletindo uma percepção da prática como algo a se condenar, invariavelmente do local. O diálogo se desenvolve:

\footnotetext{
Christian: A propósito, falando de casais, nunca houve problemas de incesto? Desculpe, mas você sabe, como pequenas comunidades ... Valentin: Bem, as linhas de sangue são muito bem preservadas. Então, os anciãos tem que aprovar a união. Os primos, por vezes, podem acasalar. Mas nós respeitamos o tabu do incesto. Então, muitas vezes, temos que convidar pessoas de fora.
}

Neste trecho é possível perceber como o incesto é marcado explicitamente como um problema para o antropólogo, um risco que decorre da baixa densidade populacional, diminuindo a possível oferta de parceiros. Valentin, por sua vez, aponta para a sujeição de Hårga à proibição do incesto, insinuando um compartilhamento da regra como, de certa maneira, um imperativo existencial que cabe respeitar ou não. Porém, a insinuação feita que decorre na percepção de que o incesto é um problema compartilhado pelos habitantes de Hårga tal qual os moldes estadunidenses, é deslocada em outra cena, deixando claro os padrões diferenciantes de construções sobre o que é o incesto, ou seja, a resposta dada à Christian não revela toda a questão para os locais. Em outra cena mais adiante, o outro antropólogo, Josh, se encontra no interior de um templo na comunidade realizando a pesquisa através do diálogo com Sven (Dag Andersson) - habitante do local, um homem na faixa dos 70 anos, responsável por presidir os rituais no vilarejo. Suas perguntas, a princípio se direcionam ao que seria e a função do Ruben RADR, um livro sagrado escritos por um dos habitantes locais, Ruben (Levente Puczkó-Smith) - um garoto apresentado como deficiente cognitivo e físico ao longo do filme - para a comunidade: 
Sven: Nós descrevemos isso [o Ruben RADR] como partituras emocionais.

Josh: $O$ que diz?

Sven: Bem, cada letra rúnica representa um dos dezesseis afetos, que são classificados do mais sagrado ao mais profano. Este, por exemplo, é sobre luto [apontando uma das letras].

Josh: Hmm.

Sven: Você pode ver no final, no entanto, que temos páginas em branco. Isso ocorre porque o Ruben RADR é um trabalho em andamento, para sempre. Para sempre evoluindo. Temos muitas, muitas centenas deles.

Josh: E quem decide o que é adicionado?

Sven: Bem, esta iteração está sendo escrita por Ruben.

Josh: Uh, os deficientes?

Sven: Desde o nascimento. [referindo-se a Ruben]

Sven: Ele desenha e nós, os mais velhos, interpretamos. Veja bem, Josh, Ruben não está coberto pela cognição normal. Isso o torna aberto para a fonte.

Josh: Uh, o que acontece quando Ruben morre? Você apenas espera um bebê não-coberto [pela cognição, racionalidade]?

Sven: Não, não, não. Rubin é um produto de endogamia. Todos os nossos Oráculos são produtos deliberados de consanguinidade.

Se nas primeiras falas expressas no diálogo entre Christian e Valentin insinuava-se uma similitude conceitual acerca do incesto, com o diálogo entre Josh e Sven fica marcada a diferença nodal. No campo antropológico, algumas reflexões desenvolvidas sobre o tema possuem grande importância, com destaque para a clássica análise de Lewis Morgan em Ancient Society (1877). Neste texto, Morgan (1877) argumenta que a proibição do incesto deriva de uma observação primitiva sobre os riscos biogenéticos resultantes da endogamia, isto é "foi produzida pela exclusão gradual dos próprios irmãos e irmãs da relação matrimonial, cujos males não poderiam escapar para sempre da observação humana" (MORGAN, 1877, p.424, tradução nossa). Esta derivação do incesto como observação da natureza reflete a noção de parentesco consanguíneo explorada por Schneider (2016) que fundam as noções "americanas", refletindo o posicionamento dos antropólogos em "Midsommar" como reflexo da postura da proibição do incesto decorrente de possíveis riscos genéticos.

Se a postura "americana", apropriando-se do termo de Schneider (2016), em "Midsommar" pode se resumir nas argumentações de Morgan (1877), ainda há certa carência de elementos que permitam pensar a constituição do incesto em Hårga a partir de seus pressupostos. $O$ incesto como instituição que refletiria riscos biogenéticos seria uma explicação que dá conta apenas de parte

CSOnline - Revista Eletrônica de Ciências Sociais, Juiz de Fora, n. 32 (2020). 
da percepção do problema em "Midsommar", pois refletiria apenas a percepção dos não-habitantes de Hårga. Haja vista a flagrante dificuldade de lidar com a questão do incesto contextualmente e propositalmente realizado, Roy Wagner (1972) oferece importantes aportes para a análise: ao definir a proibição do incesto como uma questão tautológica em que as categorias de parentesco já definem a priori o campo relacional, Wagner (1972) aponta a necessidade de situar a questão não a partir de pressupostos universais, mas pela contextualização (quando cabível) nativa. Tomando os pressupostos de seu orientador, David Schneider, Wagner (1972) aponta que onde a definição de parentesco (a partir da ótica ocidental do parentesco consanguíneo e por afinidade) não se aplica, uma análise do incesto não se constitui a partir de nossos pressupostos:

A noção de incesto pressupõe uma concepção do papel de parentesco e, onde nenhuma concepção desse tipo é encontrada, o termo é inaplicável, exceto talvez como uma "projeção" por parte do observador. A noção de exogamia depende de maneira semelhante da conceituação de unidades sociais. É importante aqui distinguir entre o uso descritivo desses termos para "encobrir" os atos comportamentais, como se pode fazer ao falar de "incesto" entre documentos ou de tropas "exogâmicas" de primatas, e o reconhecimento de comportamento incestuoso ou exogâmico como significativo para os próprios atores. No primeiro caso, o "parentesco" e as "unidades sociais" envolvidas são construções do observador, e o "incesto" e a "exogamia" derivam sua relevância apenas do uso de tais comparações sociais. No segundo caso, o incesto e a exogamia podem ser tratados como categorias operativas, desde que, com certeza, seja claro o que queremos dizer com eles e o que os sujeitos de nosso estudo querem dizer com eles" (WAGNER, 1972, p. 602)

Isto é, trata-se aqui de pensar a possibilidade analítica do incesto a partir da contextualização nativa, caso exista e seja relevante, e não por uma derivação imposta a partir de pressupostos ocidentais dados como universais. Consequentemente, podemos tratar as falas do personagem Sven a partir desta chave de leitura, ou seja, o incesto como uma questão relevante em Hårga, mas que se

CSOnline - Revista Eletrônica de Ciências Sociais, Juiz de Fora, n. 32 (2020). 
constitui por outras perspectivas. Tal como é apresentado acima, a percepção do incesto como produtor de diferenças humanas é uma ideia compartilhada tanto pelos antropólogos como pela comunidade de Hårga, porém, na comunidade não se dá como proibição, e sim como necessidade orientada. Se a proibição do incesto é constituída a partir de seu caráter negativo de restrição entre os "americanos", a necessidade contextual-relativa do incesto em Hårga possui caráter positivo, no sentido de produzir pessoas "livres" da névoa cognitiva, racional, permitindo uma construção relacional com as divindades, os não-humanos. A endogamia em Hårga é um recurso controlado na produção de oráculos, orientados pela não-racionalidade. Desta maneira, tomar o contexto nativo (e aqui particularmente fictício) como central para pensar a possibilidade de existência de noções de incesto, como propõe Wagner (1972), faz com que, comparativamente, a diferença entre americanos e habitantes de Hårga resida basicamente no efeito do ato: de um lado, o incesto produziria deficiências, resultados não desejáveis ${ }^{11}$ frutos da endogamia efeito negativo; de outro, o incesto produz oráculos, pessoas que relacionam humanos e não-humanos (divindades) - efeito positivo.

\section{3) A mutualidade do ser como chave de leitura do parentesco em Midsommar}

Por fim, resta ainda descrever o ponto que pode definir de maneira substancial a questão da constituição do parentesco na comunidade de Hårga. Para tanto, há a necessidade de recorrer às descrições de ao menos quatro cenas emblemáticas, que apontam para a mesma direção: 1) em uma das primeiras cenas do filme de real impacto, momento em que os visitantes ainda participam dos primeiros ritos na comunidade, ocorre o ättestupa ${ }^{12}$, um ritual em que dois idosos de 72 anos, por conta da idade, se sacrificam ao pular de um penhasco, um deles não morre de imediato e suas pernas feridas revelam fraturas expostas. Enquanto

\footnotetext{
11 E cabe aqui, mais uma vez, apontar que a importância dos estudos de Lévi-Strauss (1982) sobre a questão do incesto e os riscos da endogamia, não sustentados nem pela própria genética ocidental. 12 Suposta prática realizada entre os povos suecos no período pré-cristão (até finais do século XI, quando os primeiros reis declaradamente cristãos assumiram o trono), que consistia no auto-sacrifício de idosos a fim de poupar recursos, alimentos e atenção (uma forma de senicídio), já que estes não podiam mais contribuir com o grupo. O nome ättestupa remete ao termo AEttarstapi (precipício da dinastia) presente na saga islandesa Gautreks, que descreve uma família avarenta que opta em sacrificar seus idosos ao invés de gastar suas riquezas com hospitalidade. Ainda que o termo tenha se popularizado, nomeando diversos precipícios suecos, não há nenhuma evidência de que o ättestupa realmente tenha ocorrido em algum momento na região. Para mais informações sobre a suposta prática, consultar: ODÉN, Birgitta (1996). Ättestupan - mył eller verklighet?. Scandia: Tidskrift för Historisk Forskning. 62 (2): 221-234. 1996
}

CSOnline - Revista Eletrônica de Ciências Sociais, Juiz de Fora, n. 32 (2020). 
agonizava, o grupo de pessoas nativas de Hårga que observava o sacrifício agonizava em conjunto, expressando um compartilhamento da dor, que cessa apenas quando o idoso recebe fortes marretadas em seu crânio, precipitando a inevitável morte. 2) Já depois da metade do filme, quando o personagem Christian bebe um chá a ele oferecido durante uma comemoração de escolha da "rainha de maio" - título este concedido à mulher que, após tomar o mesmo chá oferecido a Christian, é capaz de resistir por mais tempo dançando em volta de um mastro de madeira enfeitado sem sentir-se mal e cair. Este título concede à vencedora a responsabilidade por abençoar as plantações, realizar oferendas aos deuses e escolher um dos seres humanos selecionados previamente para se tornar sacrifício na última celebração do festival. Tal chá é descrito por alguns dos moradores de Hårga como capaz de reduzir as defesas e abrir o sujeito às "influências" 13 . Posteriormente, Christian, sob o efeito do chá, acaba se entregando ao desejo sexual por Maja (Isabelle Grill), uma habitante de Hårga que nutre uma paixão por Christian. No ato sexual, realizado num grande celeiro em que apenas mulheres poderiam entrar, Maja e Christian se relacionam acompanhados por várias outras mulheres nuas de diversas idades, que observam o ato acariciando seus corpos e gemendo, como se estivessem diretamente participando do ato. 3) Quando Dani, após vencer a competição de resistência e se tornar a "rainha de maio" descobre a "traição" de Christian, ao ouvir os sons de gemidos no celeiro, indo verificar seus motivos e se deparando com a cena de sexo. Sua reação imediata é de espanto, levando-a a correr até um quarto e debulhar-se em lágrimas de forma solitária. Porém, diversas outras mulheres nativas de Hårga a procuram para compartilhar o choro e sofrimento em conjunto. Nesta cena, todas as mulheres choram e gritam em conjunto, como se fossem apenas um corpoum compartilhamento de sofrimento. 4) E quando, já nas últimas cenas do longa-metragem, no ritual final de Midsommar, em que três pessoas são levadas a um templo de madeira (duas voluntárias e uma escolhida pela "rainha de maio") para serem oferecidas em sacrifício, queimadas junto aos corpos de outros sujeitos mortos por razões variadas ao longo do filme, as pessoas que acompanham o incêndio gritam e se debatem em desespero, como se elas mesmas estivessem no templo e sofressem pelo fogo.

\footnotetext{
${ }^{13}$ Possivelmente, a principal razão do chá ser oferecido á Christian é sua capacidade de diminuir as "defesas" sociais, isto é, o controle aos impulsos e desejos e sua capacidade de abrir o sujeito às influências de sua vontade. Isto não quer dizer que o efeito expresso em outros personagens seja o mesmo.
}

CSOnline - Revista Eletrônica de Ciências Sociais, Juiz de Fora, n. 32 (2020). 
Em todos os trechos de cena aqui selecionados, o ponto comum é a perspectiva de compartilhamento de sentimentos e emoções vividas, ou seja, as cenas em que os personagens do filme compartilham as emoções e sentimentos de outros, sem que estejam empiricamente afetados. Como descrito nas cenas, podemos perceber como "Midsommar" mostra como o modelo de indivíduo auto-contido perde espaço face a uma vivência que extrapola os limites materiais do corpo, sendo o sentimento que vaza e que afeta outrem, aqui visto não como diferente, mas parte também de si, de uma vida compartilhada. Neste sentido, Marshall Sahlins (2013) contribui de forma significativa ao campo de estudos do parentesco e ao contexto da presente análise do filme. A "mutualidade do ser" (SAHLINS, 2013), expressa na primeira parte de seu livro "What Kinship Is... And Is Not", aparece como conceito central para pensar parentes como "pessoas que participam intrinsecamente da existência um do outro; eles são membros um do outro" (SAHLINS, 2013, p.3, tradução nossa). Sahlins (2013) aponta inicialmente uma série de exemplos que desconstroem qualquer ideal do parentesco como corolário de uma fonte biológica, uma forma de relacionamento intrínseca ao ser humano, situando tal fenômeno numa multiplicidade existencial em que, por exemplo, entre os Pamona de Sulawesi ${ }^{14}$ o parentesco não se dá por qualquer prática comparável ao pressuposto biológico. Mas, para que a oposição natureza-cultura não se dê de forma tão direta, Sahlins (2013) também apresenta exemplos, como dos habitantes do vale de Nebilyer, na Nova-Guiana ${ }^{15}$, em que a fonte do parentesco pode ser localizada por formas variadas. Por consequência, o parentesco se define para o autor como "uma variedade participações intersubjetivas, ou seja, uma rede das mutualidades do ser" (SAHLINS, 2013, p.19, tradução nossa).

Por um lado, a "mutualidade do ser" possui implicações em práticas transpessoais de coexistência, pois parentes compartilham experiências, alimentação, sofrimento e desejos, ou seja, se implicam uns nos outros. Por outro lado, a mutualidade do ser permite descrever as diversas formas de constituição do parentesco, seja por via paralela às explicações biológicas, ou sua

\footnotetext{
${ }^{14}$ Onde as crianças mudam de casa várias vezes ao longo da vida, o que denota uma construção de parentesco não por via de uma ligação intrínseca entre mãe/pai e filhos, mas como fonte constitutiva da convivência e alimentação conjunta.

${ }^{15} \mathrm{~A}$ fonte do parentesco se dá tanto pelo sêmen e leite materno quanto pela alimentação conjunta, pois todos estes elementos possuem kopong (gordura, graxa), um princípio que constrói o parentesco. Desta forma, tanto os filhos possuem parentesco entre si e com o pai/mãe em termos concebidos de forma "biologizante", quanto a comensalidade com outros sujeitos, inclusive estrangeiros, pode construir parentesco.
}

CSOnline - Revista Eletrônica de Ciências Sociais, Juiz de Fora, n. 32 (2020). 
perspectiva construída a longo da vida, ou ainda combinações de ambos.

Na visão exposta por Sahlins (2013), a mutualidade do ser abrange desde as maneiras constitutivas do parentesco, as substâncias e sentimentos comuns, até as motivações lógico-significativas para as distintas práticas de pessoas relacionadas. Na segunda parte do livro, em que Sahlins (2013) constrói sua argumentação em torno de diversos exemplos etnográficos que apresentam uma discussão do parentesco muito além do pressuposto biológico, presente em diversas análises que buscam diferenciar o parentesco real, de sangue, do fictício, por afeição, construção de substância e/ou por aliança. Mesmo tal percepção do parentesco não pode se apresentar como universalmente compartilhado, pois são também (e principalmente) "dotações sociais significativas que situam a criança em um campo amplamente ampliado e especificamente estruturado de relacionamentos de parentesco" (SAHLINS, 2013, p.74, tradução nossa). A criança, por excelência já se conecta a amplos círculos constituídos de parentes e formas morais de construção relacional ideal desde antes do nascimento, ou seja, as relações biológicas de parentesco já são, em si, relações sociais.

Sahlins (2013) defende que o nascimento não é um fato prédiscursivo e natural que se constitui a priori de formas construídas de parentesco. Pode-se não conceber relações anteriores ao nascimento (Kamea), reconhecer apenas a ligação substancial apriorística do pai (Jivaro) ou a mãe (Araweté) em relação à criança, ou ainda que se reconheça a contribuição dual para o feto, as substâncias podem ser complementares (Tlingit) ou antagônicas (Daribi), entre outros fatores que incluem não apenas as relações entre genitores (se assim concebidos em termos ocidentais), mas com linhagens, ancestrais, espíritos e outros sujeitos. Isto é, "o nascimento humano é uma função semiótica de uma ordem de parentesco, em vez de parentesco uma sequência biológica de nascimento" (SAHLINS, 2013, p.87). A variabilidade intangível do parentesco não pode ser pensada em termos de uma constante fisiológica.

Neste sentido, o ser intersubjetivo de Sahlins (2013) se configura como uma entidade simbólica, não material, que não reproduz qualquer lógica relacional que toma o ego e outrem como entidades em si que se relacionam constitutivamente de forma dialética, reproduzindo a lógica da mercadoria. Este ser intersubjetivo se aproxima da ideia de "participação" em LevyBruhl, que compreende seres que não se dão de antemão, são

CSOnline - Revista Eletrônica de Ciências Sociais, Juiz de Fora, n. 32 (2020). 
relações que precedem qualquer coisa. Esta concepção, caracterizada por Sahlins (2013) como um pensamento simbólico que se opõe à lógica racional-ocidental pressupondo separações dadas, como sujeito e objeto, eu e outro, natureza e cultura, etc que é experiencial ${ }^{16}$ por essência, tal como significada simbolicamente. A unidade de ação não é o indivíduo, mas a relação, fugindo assim da dicotomia holismo e individualismo, que termina por tomar o indivíduo como dado ontológico. Nota-se então, que o peso à questão simbólica como configurada em Sahlins (2013) não busca reproduzir uma lógica que se dá como sinônimo de qualquer ideia de representação metafórica de outras coisas, mas um apontamento opositivo à lógica ocidental que tem por modus operandi certa objetividade científica. O simbólico em Sahlins (2013) não se coloca como representação de uma realidade externa (lógica ocidental), mas se configura como oposição a lógica científica, que se vê como "descobridora" de uma realidade externa.

Seguindo esta linha analítica, é possível pensar a constituição dos eventos de expressão de sentimentos e emoções coletivas em "Midsommar" aqui mobilizados como um tipo de constituição do parentesco em Hårga enquanto expressão ou exemplo fictício daquilo que Sahlins (2013) chama de "mutualidade do ser", apontando exatamente para a perspectiva de intrínseca participação da vida de um em outros. A constituição deste ser intersubjetivo se dá em Hårga pela percepção da relação como padrão antecipatório da existência, isto é, um sujeito relacional que não se dá a priori como entidade relativamente autônoma e separada - o ego e o outrem não se dão por antecipação. Em outras palavras, o compartilhamento do prazer sexual, da dor, da morte, da tristeza, etc em "Midsommar", permite pensar estas cenas em termos do deslocamento da perspectiva ocidental em função de seres que implicam e misturam suas existências uns nos outros. A dor do idoso, o prazer de Maja, a tristeza de Dani e as queimaduras dos sacrificados ecoam no grupo, são por eles sentidos, implicam o compartilhamento.

Este compartilhamento é em Hårga elemento significante do parentesco, já que as mortes dos sujeitos externos à comunidade não são assim vivenciadas. Tanto a morte dos idosos como a dos sacrificados pelo fogo, juntamente com a cena do prazer sexual

16 Vale aqui lembrar do exemplo maori apresentado pelo autor, em que o sujeito narra os feitos e situações ancestrais empregando o pronome "eu" nas narrativas, pois compreende que os feitos ancestrais são também seus feitos, ele experencia o que o outro viveu, são pessoas implicadas umas nas outras também de forma diacrônica.

CSOnline - Revista Eletrônica de Ciências Sociais, Juiz de Fora, n. 32 (2020). 
compartilhado se dá através de membros da comunidade. Dani, por sua vez, inicia sua jornada como elemento externo, mas ao longo do enredo torna-se mais integrada, encontrando em sua vitória como "rainha de maio" o evento central para que se torne, enfim, parte de Hårga, o que se confirma no compartilhamento da tristeza haja vista a traição de Christian. Estas questões apresentam, na relação com a mutualidade do ser em Sahlins (2013), uma possibilidade (ainda que fictícia) de apresentar o parentesco como potencialidade de vivência para além da pretensão universalista do parentesco americano de Schneider (2016) e a dicotomização de sangue (dado) e afinidade (construído), tendo as relações derivadas como corolários ontológicos, como definia Morgan (1871). A questão não é negar a consanguinidade definida pela biogenética, mas sim perceber seus símbolos (sangue, DNA, etc) como pontos mais ou menos constituintes de relações de parentesco ocidentais. Porém, estas relações biogenéticas não se fundam como condições sine qua non para a constituição do parentesco, já que o este é radicalmente distinto em diversos contextos. Em Hårga, parentesco não se define apenas por sangue e nem por casamento, mas pelo compartilhamento da vida, das práticas, da vivência conjunta, da implicação existencial mútua, da fluidez dos limites do corpo. Se a noção de endogamia existe e, consequentemente, alguma ideia de consanguinidade, sua razão de ser se funda em relação ao grupo e aos deuses, mas o sangue não se estende para além disso. Ser parente em Hårga, como Midsommar apresenta, é misturar vidas, implicar a existência de um no outro.

\section{Animismo: forma de existência e orientação ética em Hårga}

Este segundo tópico objetiva-se em propor uma análise mais sucinta tendo em vista a noção de animismo como ponto central de uma reflexão ontológica em Hårga. Cabe, entretanto, apontar que esta sessão deve ser entendida como intrinsecamente relacionada ao tema do parentesco, tendo muitos de seus pontos estreitamente vinculados ao tema. Neste sentido, é importante abordar algumas cenas do filme que possam levantar elementos para uma discussão sobre a questão do animismo: no início do filme, antes de chegar propriamente em Hårga, o grupo de visitantes estacionam o carro perto da entrada da comunidade, sendo recebidos por alguns habitantes locais, que oferecem um

CSOnline - Revista Eletrônica de Ciências Sociais, Juiz de Fora, n. 32 (2020). 
chá $^{17}$ que gera diferentes efeitos nos sujeitos, mas o que se destaca é o que se produz em Dani, que vê crescer em suas mãos uma vegetação rasteira, gramíneas, como se fizesse parte da natureza. Também é possível observar a semelhança de efeitos que acomete Dani e Pelle (único do grupo de amigos que é nativo de Hårga), mesmo em meio a tantas variações. Neste trecho, Pelle diz: "Olhe, as árvores estão respirando. A natureza sabe como estar em harmonia, é instintivo. Tudo faz sua parte, mecanicamente". Coincidentemente, os efeitos vistos sob a ótica de Dani expressam exatamente a fala de Pelle (apenas compartilhada pelos dois), sendo possível perceber movimentos respiratórios na vegetação em torno.

Já na metade do filme, enquanto os dois antropólogos, Christian e Josh, conversam com Pelle (amigo de ambos e nativo de Hårga, o personagem que apresenta a comunidade aos amigos) em um campo aberto, e os habitantes realizam diversas tarefas, tal como cuidar de animais, preparar enfeites e etc, Mark - amigo dos antropólogos Christian e Josh e do nativo Pelle, caracterizado como personagem de veia cômica e grande egoísmo, preocupa-se ao longo do filme apenas com a possibilidade de ter relações sexuais com uma das nativas - se isola do grupo em direção a uma árvore caída para urinar, o que desperta grande fúria e desespero em um dos habitantes locais, Ulf (Henrik Norlén), que corre em sua direção em meio a gritos:

Ulf: [suas falas são todas em sueco, fazendo com que Mark não seja capaz de se comunicar com Ulf] Não, não! O que você está fazendo?

Ulf: Seu idiota, o que você está fazendo? Saia daí! Tire seu pau nojento daí!

Mark: O quê? Calma! Ok, calma! O que eu fiz?

Ulf: Estes são nossos antepassados!

Mark: Pelle, o que aconteceu?

Ulf: Você está mijando em meus antepassados!

\footnotetext{
17 Não há confirmação se o chá é o mesmo do descrito da sessão anterior. Independentemente, quando diferentes personagens tomam o mesmo chá, é possível observar distinções nos efeitos de forma significativa. Para tanto, a questão dos efeitos serem ou não definidos como alucinógenos no sentido da distorção de uma realidade objetiva - não é aqui tomado como significativo, mas sim os efeitos e possíveis explicações e reflexões produzidas na narrativa do longa e as consequências destes.
}

CSOnline - Revista Eletrônica de Ciências Sociais, Juiz de Fora, n. 32 (2020). 
Ulf [falando com Pelle, um dos nativos e amigo de Mark, que fala inglês e sueco]: o seu amigo está mijando em Rotvälta ${ }^{18 !}$

Mark: O que eu fiz? O que eu fiz?

Pelle [se referindo à Mark]: Você urinou em uma árvore ancestral.

Mark: A árvore? O quê?

Pelle: Esta árvore está ligada aos nossos mortos.

Mark: Mas é uma árvore morta!

Pelle: Ela é importante para nós.

Na parte final do filme, em meio à competição de dança que elegeria a rainha de maio, todos tomam o chá. Na ótica de Christian os efeitos dizem respeito, como já analisado, à queda de defesas sociais (fidelidade ao namoro) e abertura aos desejos do sujeito, refletidos na relação sexual com Maja. Não há nenhuma mudança na natureza em torno. Na ótica de Dani durante a dança da rainha de maio, após tomar o chá, observa mais plantas crescendo em seus pés e a respiração da vegetação circundante. Mesmo com o fim da dança, após ser eleita rainha de maio e oferecer carne e grãos aos deuses, abençoando também as plantações, além de presenciar posteriormente a traição de Christian com Maja, os efeitos persistem. Dani é envolvida dos pés à cabeça com flores durante a última refeição do festival de Midsommar e, ao sentar em sua cadeira, observa como as plantas colocadas reagem aos movimentos de suas mãos, como se fossem extensões de si. As flores que envolvem seu corpo também reagem à Dani, acompanhando sua respiração por meio de movimentos de abrir e fechar. Sendo a única personagem externa à comunidade que alcança este tipo de efeito pós-chá e, vencendo a competição da rainha de maio, Dani termina o filme integrada a comunidade de Hårga, o que insinua sua posterior vivência no local, fazendo parte de uma nova família e rompendo com o ciclo de solidão após sua tragédia familiar.

A partir destes trechos, é possivel traçar um padrão relacional entre humanos e não-humanos (neste caso, a árvore) na questão do parentesco, desta vez relacionado ao animismo. Sahlins (2013) aponta que a noção de mutualidade do ser não se aplica apenas nas relações entre sujeitos humanos (partindo na noção biológica

\footnotetext{
18 Palavra sueca que designa o fenômeno, traduzido para o inglês "Windthrow", em que árvores são desenraizadas do solo pela força do vento, mas que podem servir como base para o desenvolvimento de nova biodiversidade a partir do tronco caído.
}

CSOnline - Revista Eletrônica de Ciências Sociais, Juiz de Fora, n. 32 (2020). 
de espécies), mas se estende também para outros humanos ${ }^{19} \mathrm{e}$ não-humanos, envolvendo relações trans-específicas, nas quais as plantas são filhas das mulheres na Amazônia, ou os animais que são parentes dos caçadores na Sibéria e na Amazônia, etc. "Isso não é metáfora, mas uma sociologia da conduta moral, ritual e prática" (SAHLINS, 2013, p.30, tradução nossa). Tais relações trans-específicas apontadas por Sahlins (2013) possuem forte influência das proposições de Viveiros de Castro (2009) sobre pensar vários temas, entre eles parentesco e animismo como problemas fundados na mesma questão: "o problema da intencionalidade e influência, a misteriosa eficácia da relacionalidade" (VIVEIROS DE CASTRO, 2009, p.244, tradução nossa). O animismo ao ser definido como meio em que pessoas e coisas assumem a forma de pessoas, a potencialidade da agência não mais separa sujeito (humano, polo ativo) e objeto (não-humano, polo passivo), mas se estende universalmente e se expressa pelo parentesco.

Outro autor de ampla relevância ao tema do animismo é Graham Harvey (2014), que resgata a ideia do animismo para pensar movimentos mais contemporâneos no ocidente (como o neopaganismo) e outros contextos não ocidentais. Ainda que o termo ressoe sua origem no pensamento antropológico em Tylor (1929), que o expressa como uma ilusão na atribuição da alma a diversos seres e coisas, estendendo-se até a modernidade religiosa, a base de Harvey (2014) é identificada mais em associação ao trabalho de Hallowell (1960) entre os Ojibwa, em que o animismo se refere a um modo de vida que pressupõe um mundo formado por comunidades de seres vivos e que pressupõe uma ética de comportamento, neste sentido assemelhando-se das propostas de Sahlins (2013) e de Harvey (2014): "O 'animismo' pode rotular a etiqueta entre espécies [...], bem como suas preocupações ontológicas e / ou epistemológicas" (HARVEY, 2014, p.5). Também e, talvez principalmente, designa uma correlação com o termo base, "anima", sugerindo um aspecto estimulante, uma essência viva dentro de animais, plantas e/ou pedras, tal como espíritos, deuses e etc. O animismo aponta para a descrição "atos performativos em que as pessoas se envolvem com outras espécies ou com coisas materiais" (HARVEY, 2014, p.7), isto é, traz a

\footnotetext{
19 Aqui, a ideia é abarcar noções de humanidade mais amplas, como por exemplo entre os ameríndios analisados por Eduardo Viveiros de Castro que, sucintamente, entendem a humanidade a partir de um pressuposto às "relações sociais" com semelhantes. Tal proposição inverte a lógica natureza-cultura e coloca a "cultura", isto é, os pressupostos de caça, alimentação, cauinagem e etc como padrão universal estendido à todas as espécies e a diferença corporal como ponto de secção inter-específico, ainda que também tenha caráter potencial, abarcando capturas e mudanças corporais.
}

CSOnline - Revista Eletrônica de Ciências Sociais, Juiz de Fora, n. 32 (2020). 
performatividade da relação entre humanos e não-humanos como seres passíveis de ética comportamental justamente por compartilharem um pressuposto de vida, de anima.

Nos trechos do filme aqui assinalados, a questão do animismo é altamente significativa. Na descrição da cena em que Mark urina na árvore morta, a reação de Ulf denota um horror ao ato, resultado de um padrão ético de comportamento com estes seres. Tal como é impensável a ideia de urinar em cadáveres humanos, o animismo em Hårga implica em padrões ético-comportamentais com seres vivos não-humanos. E como Viveiros de Castro (2009) aponta, a expressão desse padrão comportamental animista se dá através do idioma do parentesco, em que Rotvälta é ancestral de Ulf e de todos em Hårga, é um corpo de um parente morto. Neste sentido, tanto Sahlins (2013) quanto Harvey (2014) também apontam o animismo como construção existencial que decorre em padrões éticos de comportamento para além da esfera humana, o que reforça a tese do horror de Ulf ao ato de Mark. Este padrão ético de comportamento animista, em resumo, que estende a nãohumanos uma relação também humana se dá pelo idioma do parentesco - a forma conectiva entre agentes variados.

Paralelamente, nas outras cenas descritas em que Dani (e possivelmente Pelle) observa plantas e árvores respirando, a analogia ao animismo é também possível através da fala de Pelle sobre a respiração das árvores, denotando a sua percepção destes seres enquanto organismos vivos análogos à humanidade. Num movimento oposto, as cenas em que Dani vê suas mãos e pés como partes da vegetação rasteira aludem à percepção de que humanos e natureza estão tão integralmente imbricados que, em essência, fazem parte da mesma existência. Este posicionamento rompe com o dualismo cartesiano de separação de sujeitos e objetos, sendo o primeiro termo pressuposto inevitavelmente humano, que também ecoa na proposição de Schneider (2016) que trata o parentesco americano através da dicotomia humanos versus natureza, em que a natureza expressa o reino a se dominar e controlar. O animismo de Hårga expresso visualmente nas cenas das mãos e pés de Dani como parte da vegetação é reforçado em um cântico realizado por um ancião antes de uma refeição logo nos primeiros momentos dos personagens no vilarejo, traduzida pelo personagem Pelle, refletindo a relação harmônica entre 
humanos e não-humanos numa perspectiva, de certa maneira, panteísta $^{20}$ :

Christian: ele estava rezando?

Pelle: Não, ele não estava rezando, estava agradecendo por ser transformado em ... tudo. A harmonia e o equilíbrio.

Aqui, por fim, é possível destacar como consequência uma dupla via no animismo em "Midsommar": de um lado, as árvores que respiram como humanos implicam um compartilhamento de pressupostos dados como humanos na natureza, isto é, um resgate de sua percepção como ser vivo, não objeto. De outro lado, a percepção do corpo humano como parte da natureza implica em uma "naturalização" do humano, no sentido de destacar que não apenas a natureza é humana enquanto ser viva e necessitar de comportamentos éticos, mas a humanidade também é parte da natureza. Vale frisar que a pretensa separação entre humano e natureza retratada em algumas cenas do filme não vem reforçar a dicotomia, mas, ao contrário, embaralhá-la. As cenas descritas podem destacar um animismo de tipo ético-comportamental que encontra no idioma do parentesco sua forma de expressão, mas que pressupõe um posicionamento ontológico que busca afirmar uma realidade perdida para os ocidentais, um monismo existencial que (re)une humanos e natureza e indica uma ética de ação e comportamento, atribuindo - como o animismo de Harvey (2014) indica - um pressuposto de ação compartilhada, um percepção de sujeito estendida para além do humano.

\section{Conclusão}

Ao propor uma aproximação da antropologia com o filme "Midsommar", as escolhas analíticas feitas não se dão ao léu; "Midsommar" realmente possui forte conteúdo de caráter antropológico diluído em seu enredo para além dos dois personagens identificados como antropólogos, sem perder sua essência enquanto filme de terror.

Em termos gerais, a linguagem do filme provoca uma reflexão sobre a alteridade ao opor dois modos de vida básicos: o ocidental e o

\footnotetext{
20 Posicionamento popularizado pelo filósofo Baruch de Espinosa (ainda que não seja o criador) que pressupõe o compartilhamento substancial imanente de todos os seres da "natureza". Deus seria não um ser transcendente e pessoalizado, mas imanente a tudo, portanto essa equiparação humano e não-humano expressa em "Midsommar" ressoa como uma perspectiva panteísta.
}

CSOnline - Revista Eletrônica de Ciências Sociais, Juiz de Fora, n. 32 (2020). 
de Hårga. Ainda que o objetivo do longa seja voltado ao entretenimento, variadas situações com implicações antropológicas e filosóficas se colocam, o que resultam em diversos momentos em que perspectivas éticas se confrontam ${ }^{21}$ fundadas na questão dos limites potenciais da alteridade. Em termos antropológicos, a proposta de levar à sério a comunidade de Hårga enquanto local potencial de realização etnográfica e o conteúdo do filme como material de análise, revela-se que o parentesco e o animismo podem ser definidos como dois idiomas centrais na constituição existencial (ontológica) e no modus operandi daquele contexto. O confronto com perspectivas ocidentais, elemento este frequente ao longo do filme, exercita o "estranhamento" antropológico e permite a realização da análise.

Em última instância, o objetivo foi realizar através da antropologia uma reflexão sobre uma obra cinematográfica como recurso analítico que evidencia - mesmo que através da ficção possibilidades existenciais alternativas às formas ocidentais, trazendo à tona de uma forma acessível ao grande público fora da academia, o problema do confronto com a alteridade através da linguagem do parentesco e do animismo. Estes dois temas, como aqui buscou-se defender, se relacionam na formação constitutiva das perspectivas ontológicas de Hårga, destacando o atributo humano enquanto agente existencial prioritário um corolário atribuível não apenas ao que comumente chamamos de humano (Homo-sapiens), mas aos diversos seres que nos circundam. Vale frisar que esta perspectiva de "humano" pode ser aqui pensada, a partir das formulações de Sahlins (2013), como um pressuposto de relacionalidade não-hierárquica - como impõe a separação humano (polo ativo) e natureza (polo passivo) - que realiza numa linha aqui caracterizada por um tipo de animismo o parentesco de Hårga. Este parentesco não se define enquanto atribuição derivada de compartilhamento de substância genética ou por relação de afinidade constituída, mas por uma extensão do ser para além dos limites materiais do corpo, uma mutualidade existencial. Isto é, o ser humano enquanto espécie não possui destaque nas relações constituídas, que se dão tanto por uma planicidade em relação com não-humanos (árvores, por exemplo), quanto pela natureza das mesmas relações mutualidade que, por não separarem seres enquanto mônadas auto-contidas, pensam e

\footnotetext{
${ }^{21}$ E podemos aqui citar, por fim e novamente, a cena em que dois idosos se sacrificam em um penhasco. Alguns dos personagens, os turistas britânicos Connie (Ellora Torchia) e Simon (Archie Madekwe), se horrorizam pelo ato e ameaçam deixar o lugar, confrontados no caminho pela local Siv (Gunnel fred), que tenta explicar os diferentes modos de pensar a agir sobre a morte.
}

CSOnline - Revista Eletrônica de Ciências Sociais, Juiz de Fora, n. 32 (2020). 
vivenciam os sentimentos e emoções como experiências coletivas em Hårga. Por fim, o que talvez mais se evidencie no longa em relação a antropologia, seja exatamente o confronto de possibilidades existenciais diferenciantes que opõem o modelo de Hårga do "americano" ocidental, englobando perspectivas diversas, como a questão do incesto e formação de parentesco, o animismo e etc, permitindo assim pensar o longa como um tipo de terror antropológico, como algumas críticas ${ }^{22}$ de cinema vem apontando.

\section{Filmografia}

MIDSOMMAR. Direção de Ari Aster. Estados Unidos / Suécia. A24; Parts \& Labor; B-Reel Films. 2019

\section{Bibliografia}

HALLOWELL, Alfred Irving. Ojibwa Ontology, Behavior, and World View. In: RADIN, Paul; Diamond, Stanley (ed.). Culture in History: Essays in Honor. New York: Columbia University Press. Reprinted in Graham. 1960

HARVEY, Graham. Introduction. In: HARVEY, Graham (org.). The Handbook of Contemporany Animism. London; New York: Routledge. 2014

MORGAN, Lewis. Henry. Systems of Consanguinity and Afinity in the Human Family. Washington: Smithsonian Institution, 1871.

Ancient Society. New York: Henry Holt and Company. 1877.

SAHLINS, Marshall. What Kinship Is... And Is Not. London \& Chicago: The University of Chicago Press. 2013

SCHNEIDER, David. Parentesco Americano: uma exposição cultural. Trad: RIBEIRO, Fábio. Petrópolis: Vozes. 2016.

TSUGAMI, Susan Sanae. Runas, Sacrifício e Tradição. SCANDIA: journal of medieval norse studies. N. 2. 2019

TYLOR, Edward Burnett. Primitive Culture: researches into the development of mythology, philosophy, religion, language, art, and custom. London: John Murray. 1929

VIVEIROS DE CASTRO, Eduardo. The Gift and the Given: three nanoessays on kinship and magic. In: BAMFORD, Sandra; LEACH, James (eds.). Kinship and Beyond: the genealogical model reconsidered. Berghahn Books. 2009. pp. 237268.

WAGNER, Roy. Incest and Identity: a critique and theory on the subject of exogamy and incest prohibition. Man 7 (4). P.601-613. 1972.

22 Por exemplo, nesta crítica de Isabela Boscov: https://veja.abril.com.br/blog/isabelaboscov/midsommar-terror-antropologico/ Acesso em 20 jun. 2020

CSOnline - Revista Eletrônica de Ciências Sociais, Juiz de Fora, n. 32 (2020). 